\title{
Study on compressive strength of mineral admixtures and fibers to develop high performance concrete
}

\author{
Nivin Philip \\ Assistant Professor, \\ Department of Civil Engineering, \\ Mar Athanasius College of Engineering, Kothamangalam, Kerala. india
}

\author{
Dr. Neeraja \\ Associate Professor, \\ Department of Cvil Engineering, \\ School of Mechanical and Building Science \\ VIT University, Vellore, Tamil Nadu. india
}

\begin{abstract}
An experimental investigation was carried out to evaluate the strength properties of high performance concrete containing mineral admixtures and fibers. The paper presents a comparison of three mineral admixtures, Alccofine 1203 (AF), Metakaoline (MK) and Ground Granulated Blast furnace Slag (GGBS) on the strength properties of superplasticised high-performance concrete. Assessment of the concrete mixes was based on compressive strength of concrete on 7 and 28 days curing. The results confirmed that mineral admixtures improved the strength properties of high performance concretes, but at different rates depending on the binder type.
\end{abstract}

Keywords- Alccofine 1203, Metakaoline, GGBS,

\section{Introduction}

High Performance Concrete (HPC) is a concrete mixture, which possess high durability and high strength when compared to conventional concrete. This concrete contains one or more of cementitious materials such as fly ash, silica fume, metakaolin, Alccofine 1203 or ground granulated blast furnace slag and usually a super plasticizer. The term 'high performance' is somewhat pretentious because the essential feature of this concrete is that its ingredients and proportions are specifically chosen so as to have particularly appropriate properties for the expected use of the structure such as high strength and low permeability[1]. Hence High performance concrete is not a special type of concrete. It comprises of the same materials as that of the conventional cement concrete. The use of some mineral and chemical admixtures like silica fume and super plasticizer enhance the strength, durability and workability qualities to a very high extent [2].

High Performance concrete works out to be economical, even though its initial cost is higher than that of conventional concrete, as it enhances the service life of the structure and the structure suffers less damage, which would reduce overall costs. Concrete is a durable and versatile construction material. It is strong, economical and takes the shape of any form in which it is placed, in fresh state.
However, experience has shown that concrete is vulnerable to deterioration, unless precautionary measures are taken during the design and production. For this, the influence of components on the behaviour of concrete and to produce a concrete mix within closely controlled tolerances is to be studied.

The conventional Portland cement concrete is found deficient in respect of;

- Durability in severe environs (shorter service life and frequent maintenance)

- Time of construction (slower gain of strength)

- Energy absorption capacity (for earthquake resistant structures)

- Repair and retrofitting jobs.

Hence it has been increasingly realized that besides strength, there are other equally important criteria such as durability, workability and toughness which made to focus on 'High performance concrete' where performance requirements can be different than high strength and can vary from application to application[3]. Any concrete which satisfies certain criteria proposed to overcome limitations of conventional concretes may be called High Performance Concrete. It may include concrete, which provides either substantially improved resistance to environmental influences or substantially increased structural capacity while maintaining adequate durability. It may also include concrete, which significantly reduces construction time to permit rapid opening or reopening of roads to traffic, without compromising long-term serviceability. Therefore it is not possible to provide a unique definition of High Performance Concrete without considering the performance requirements of the intended use of the concrete.

American Concrete Institute defines High Performance Concrete as:

"A concrete which meets special performance and uniformity requirements that cannot always be achieved routinely by using only conventional materials and normal mixing, placing and curing practices". The requirements may involve enhancements of characteristics such as placement 
and compaction without segregation, long-term mechanical properties, and early age strength or service life in severe environments

\section{Materials and Methods}

\subsection{Materials}

\subsubsection{Cement}

The Ordinary Portland Cement of 53 grade confirming to IS 12269.1987 is used in the experimental programme. The Properties of cement is given in Table I

\subsubsection{Coarse Aggregates}

The $20 \mathrm{~mm}$ and $12.5 \mathrm{~mm}$ size aggregate are used. The $20 \mathrm{~mm}$ to $12.5 \mathrm{~mm}$ ratio is $63: 37$. The Coarse aggregates from crushed basalt rock, confirming IS: 383 are being used. The flakiness and elongation index were maintained well below $15 \%$. The properties of natural coarse aggregates are given in Table II.

Table I: Properties of cement

\begin{tabular}{|l|l|l|}
\hline SI No & Physical Properties of OPC 53 cement & Results \\
\hline 1 & Specific Gravity & 3.14 \\
\hline 2 & Standard Consistency & 31.5 \\
\hline 3 & Initial setting time (min.) & 30 \\
\hline 5 & Final setting time (min.) & 211 \\
\hline 6 & Compressive strength (at 7days in N/mm ${ }^{2}$ ) & 40 \\
\hline
\end{tabular}

\subsubsection{Coarse Aggregates}

The $20 \mathrm{~mm}$ and $12.5 \mathrm{~mm}$ size aggregate are used. The $20 \mathrm{~mm}$ to $12.5 \mathrm{~mm}$ ratio is $63: 37$. The Coarse aggregates from crushed basalt rock, confirming IS: 383 are being used. The flakiness and elongation index were maintained well below $15 \%$. The properties of natural coarse aggregates are given in Table II.

Table II: Properties of Coarse Aggregates

\begin{tabular}{|l|l|l|}
\hline SI No: & Particulars & Natural Coarse Aggregate \\
\hline 1 & Source & Muvattupuza, kerala \\
\hline 2 & Max. aggregate size & $20 \mathrm{~mm}$ \\
\hline 3 & Specific gravity & 2.83 \\
\hline 4 & Density & $1805.62 \mathrm{Kg} / \mathrm{m}^{3}$ \\
\hline
\end{tabular}

\subsubsection{Fine aggregates}

Those fractions from $4.75 \mathrm{~mm}$ to 150 micron are termed as fine aggregate. The crushed sand is being used as fine aggregates confirming to the requirements of IS:383. Table III shows the properties of fine aggregates. Fig.I shows the sieve analysis of fine aggregates and it belongs to grade zone II

Table III: Properties of Fine Aggregates

\begin{tabular}{|l|l|l|}
\hline SI No: & Particulars & Natural Coarse Aggregate \\
\hline 1 & Source & Muvattupuza, Kerala \\
\hline 2 & Size & $20 \mathrm{~mm}$ \\
\cline { 2 - 3 } & & IS:383-1970 \\
\hline 3 & Specific gravity & 2.53 \\
\hline 4 & Density & $1805.62 \mathrm{Kg} / \mathrm{m}^{3}$ \\
\hline
\end{tabular}

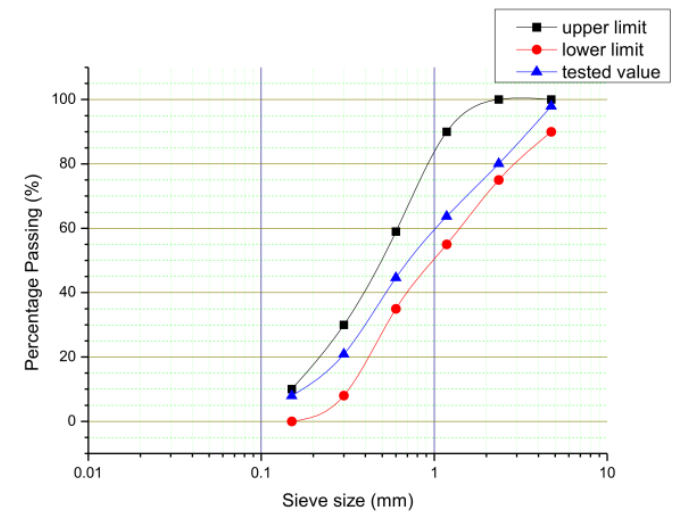

Fig I. Sieve Analysis graph

\subsubsection{Mineral Admixtures}

Three types of mineral admixtures are used for the present study. Alccofine 1203, GGBS and Metakaoline.

\subsubsection{Alccofine 1203 :}

Alccofine 1203 is a specially processed product based on slag of high glass content with high reactivity obtained through the process of controlled granulation. The raw materials are composed primary of low calcium silicates. The processing with other select ingredients results in controlled particle size distribution (PSD). The computed blain value based on PSD is around $12000 \mathrm{~cm}^{2} / \mathrm{gm}$ and is truly ultra fine. Due to its unique chemistry and ultra fine particle size, Alccofine 1203 provides reduced water demand for a given workability, even up to $70 \%$ replacement level as per requirement of concrete performance. Alccofine 1203 can also be used as a high range water reducer to improve compressive strength or as a super workability aid to improve flow.

\subsubsection{Metakaolin:}

Metakaolin is an engineered product produced from kaolin clay. Metakaolin, when used as replacements of cement in the mix is found to impart high resistance to permeability, chloride attack, sulphate attack and thereby improving the durability of the structure. Metakaolin is produced from a naturally occurring fine, alumino-siliceous clay, kaolin, by heating it to a temperature of $650-900^{\circ} \mathrm{C}$. On heating, kaolin clay changes its structure and gets converted to metakaolin. They show excellent pozzolanic reaction and react with calcium hydroxide in the concrete matrix and forms C-S-H crystals which leads to a denser and higher strength concrete.

\subsubsection{Ground Granulated Blast furnace Slag (GGBS)}

GGBS is obtained by quenching molten iron slag (a byproduct of iron and steel-making) from a blast furnace in water or steam, to produce a glassy, granular product that is then dried and ground into a fine powder. The chemical composition of a slag varies considerably depending on the composition of the raw materials in the iron production process. Silicate and aluminate impurities from the ore and coke are combined in the blast furnace with a flux which lowers the viscosity of the slag. In the case of pig iron production the flux consists mostly of a mixture of limestone and forsterite or in some cases dolomite. In the blast furnace 
the slag floats on top of the iron and is decanted for separation. Slow cooling of slag melts results in an unreactive crystalline material consisting of an assemblage of $\mathrm{Ca}-\mathrm{Al}-\mathrm{Mg}$ silicates. To obtain a good slag reactivity or hydraulicity, the slag melt needs to be rapidly cooled or quenched below $800{ }^{\circ} \mathrm{C}$ in order to prevent the crystallization of merwinite and melilite. To cool and fragment the slag, granulation process can be applied in which molten slag is subjected to jet streams of water or air under pressure. The Chemical compositions of three mineral admixtures are given in Table IV.

\subsubsection{Chemical Admixtures}

In this investigation super plasticizer- MasterGlenium SKY 8233 is based on new generation modified polycarboxylic ether polymers, The product has been primarily developed for applications in high performance concrete where the highest durability and performance is required.

Table IV: Chemical composition of Mineral Admixtures for a sample of admixture

\begin{tabular}{|l|c|c|c|c|}
\hline $\begin{array}{l}\text { SI } \\
\text { No }\end{array}$ & $\begin{array}{c}\text { Chemical } \\
\text { content }\end{array}$ & Alccofine 1203(\%) & $\begin{array}{c}\text { GGBS } \\
(\%)\end{array}$ & $\begin{array}{c}\text { Metakaoline } \\
(\%)\end{array}$ \\
\hline 1 & $\mathrm{CaO}$ & $32-34$ & $32-34$ & $0.4-0.8$ \\
\hline 2 & $\mathrm{SiO}_{2}$ & $28-32$ & $28-32$ & $50-54$ \\
\hline 3 & $\mathrm{Al}_{2} \mathrm{O}_{3}$ & $18-20$ & $18-20$ & $41-45$ \\
\hline 4 & $\mathrm{Fe}_{2} \mathrm{O}_{3}$ & $1.8-2$ & $1.8-2$ & $0.5-1$ \\
\hline 5 & $\mathrm{MgO}$ & $8-10$ & & \\
\hline 6 & $\mathrm{SO}_{3}$ & $0.3-0.7$ & & \\
\hline
\end{tabular}

MasterGlenium SKY 8233 is free of chloride \& low alkali. It is compatible with all types of cements. Chemical Admixture MasterGlenium SKY 8233 is conforming to IS: 9103-1999 was used to improve the workability of concrete. The properties of super plasticizer are shown in Table V

\subsubsection{Fibers}

Addition of small closely spaced and uniformly dispersed fibres to concrete would improve its properties like ductility and resistance to cracking. Strongcrete (polypropylene fibres), Nokrak(polypropylene fibres)[4], Flat crimped Steel fibers used for this study are shown in Fig II. The Properties of fibers are shown in Table VI.

Table V: Data sheet of chemical admixtures

\begin{tabular}{|l|l|}
\hline Title & Description \\
\hline Aspect & Light brown liquid \\
\hline Relative Density & $1.08 \pm 0.01$ at $25^{\circ} \mathrm{C}$ \\
\hline $\mathrm{pH}$ & $\geq 6$ \\
\hline Chloride ion content & $<0.2 \%$ \\
\hline
\end{tabular}

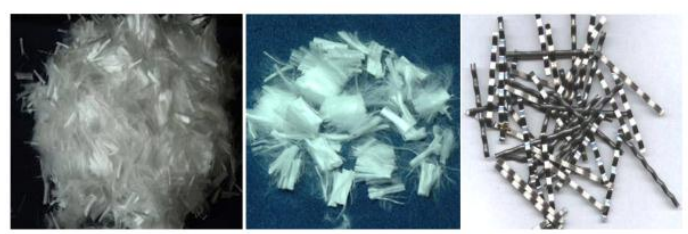

Fig. II Strongcrete Nokrack Steel fibre Table VI: Properties of Fibres

\begin{tabular}{|l|c|c|c|}
\hline Properties & Nokrack & Strongcrete & Steel \\
\hline Length & Multiples of 10/20 mm & Graded & $10 \mathrm{~mm}$ \\
\hline Construction & $\begin{array}{l}\text { Combination of straight } \\
\text { +fibrillated mesh fibre }\end{array}$ & Fibrillated & Crimped \\
\hline $\begin{array}{l}\text { Acid } \\
\text { Resistance }\end{array}$ & High & High & - \\
\hline $\begin{array}{l}\text { Alkali } \\
\text { Resistance }\end{array}$ & Completely resistant & Full & - \\
\hline $\begin{array}{l}\text { Aspect ratio } \\
\text { Tensile } \\
\text { strength }\end{array}$ & - & - & 45 \\
\hline
\end{tabular}

\subsubsection{Water}

Water is an important ingredient of concrete, as it actually participates in the hydration processes. It helps to form the strength giving cement gel, the quantity and quality of water is required to be looked into very carefully

\section{Experimental Programme}

The concrete mixes were designed as per IS 10262:2009. The final mix proportions were arrived at after having done many trials so as to have a slump between 60 and $90 \mathrm{~mm}$ at a constant water-binder ratio $(\mathrm{w} / \mathrm{b})$ of 0.30 , coarse aggregate content of $1100 \mathrm{~kg} / \mathrm{m}^{3}$ and a constant total binder content of $517 \mathrm{~kg} / \mathrm{m}^{3}$. The slump was adjusted by adding different dosages of the superplasticiser. One control mix incorporating only Portland cement (PC) and other mixes containing mineral admixtures and fibres were prepared. The effects of adding admixtures and fibres on strength were studied independently. For each trial mix, a minimum of six cubes were cast to explore 7 and 28 days compressive strength. Total 90 cubes where casted for developing a mix design for HPC. To study the effect of fibers in compressive strength of concrete, total of 90 cubes were tested. The different fibers with notation used for experimental study were given in Table VII. The percentages of Alccofine 1203(A), metakaolin (MK) and GGBS $(\mathrm{G})$ considered for the study are $5 \%, 10 \%, 15 \%, 20 \%$ and $25 \%$ by weight of cement respectively.

Table VII: Type and Percentage of fiber for design mix

\begin{tabular}{|l|c|c|}
\hline Fiber Type & Notation & $\begin{array}{c}\text { Percentage of fiber } \\
\text { (Percentage volume of } \\
\text { concrete) }\end{array}$ \\
\hline \multirow{4}{*}{$\begin{array}{l}\text { Strongcrete ( fibrillated } \\
\text { polypropylene fiber) }\end{array}$} & SG1 & $0.4 \%$ \\
\cline { 2 - 3 } & SG2 & $0.7 \%$ \\
\cline { 2 - 3 } & SG3 & $1 \%$ \\
\cline { 2 - 3 } & SG4 & $0.1 \%$ \\
\cline { 2 - 3 } & SG5 & $0.3 \%$ \\
\hline \multirow{2}{*}{$\begin{array}{l}\text { Nokrack ( combination } \\
\text { ffibrillated } \\
\text { polypropylene fiber) }\end{array}$} & $\mathrm{N} 1$ & $0.4 \%$ \\
\cline { 2 - 3 } & $\mathrm{N} 2$ & $0.7 \%$ \\
\cline { 2 - 3 } & $\mathrm{N} 3$ & $1 \%$ \\
\cline { 2 - 3 } & $\mathrm{N} 4$ & $0.1 \%$ \\
\cline { 2 - 3 } \multirow{3}{*}{$\begin{array}{l}\text { Steel fiber ( Flat } \\
\text { crimped steel fiber) }\end{array}$} & $\mathrm{N} 5$ & $0.3 \%$ \\
\cline { 2 - 3 } & $\mathrm{ST} 1$ & $0.4 \%$ \\
\cline { 2 - 3 } & $\mathrm{ST} 2$ & $0.7 \%$ \\
\hline
\end{tabular}




\begin{tabular}{|l|l|l|}
\hline & ST4 & $0.1 \%$ \\
\cline { 2 - 3 } & ST5 & $0.3 \%$ \\
\hline
\end{tabular}

\section{Results and Discussion}

The compressive strength results are presented in Fig. III to VI and the changes in compressive strength in relation to the control mix are reported in Table VIII. The compressive strength of control mix at 7 day is observed to be $60.7 \mathrm{MPa}$ and at 28 day it is $44.18 \mathrm{MPa}$. The reason for reduction in strength at 28 day age is due to the excess formation of calcium hydroxide, which will increase the volume and formation of internal cracks. Fig III shows that Alccofine 1203 at all replacement levels performed consistently better than control mix in terms of strength development. The incorporation of $20 \%$ Alccofine 1203 exhibited the best compressive strength results at both 7 and 28 days, which defines M80 concrete The compressive strength is slightly higher for $15 \%$ replacement of Alccofine 1203. Table VIII demonstrates that the enhancement in strength (that is the rate of strength development) continued for Alccofine 1203 mixes for 7 and 28 days respectively. Fig IV shows the strength development of different metakaolin mixes. The 5\% metakaolin mix achieved target strength for M80, followed by $15 \%$ replacement at 28 days, but at early age ( 7 day), the strength is slightly less, but higher than control mix. This can be seen clearly in Table VIII. The addition of 20\% and 25\% metakaolin did not result in any improvement for M80, but higher than control mix. From Fig 5, it is observed that replacement of cement by $20 \%$ GGBS gave compressive strength of $85.3 \mathrm{MPa}$ and $89.9 \mathrm{MPa}$ at 7 and 28 days respectively, which is more than target strength (M80). Improvements in compressive strength of concrete mixes containing mineral admixtures can be explained by the chemical and physical effects. Chemical effect is mainly due to the pozzolanic reactions between the amorphous silica in metakaolin, Alccofine and GGBS and calcium hydroxide $(\mathrm{CH})$ produced by the hydration of concrete to form secondary calcium-silicate-hydrates $(\mathrm{C}-\mathrm{S}-\mathrm{H})$.

Compressive strength at 7 and 28 days were tested for three different fibers in the present study to get the desired target strength. Fig 6 shows the variation of compressive strength for three different fibres, strongcrete, Nokrack and steel fibres. From the figure, it is also observed that the compressive strength values at different fibres showed marginal increase, but less than target strength. Strongcrete fiber gave maximum compressive strength of $62.36 \mathrm{~N} / \mathrm{mm}^{2}$ at 28 days at $0.3 \%$ replacement and also showed a better bonding $\mathrm{b} / \mathrm{w}$ the matrix. Nokrack fiber gave maximum strength of $58.22 \mathrm{~N} / \mathrm{mm}^{2}$ at $0.3 \%$ replacement and better

\begin{tabular}{|c|c|c|c|c|}
\hline & Table VIII: Strength of mi & $\mathrm{s}$ relative to control mix for the percenta & es selected & \\
\hline Sl. No: & Mix id & No: of cubes required for mix (3 each) & Compressi & th $\left(\mathrm{N} / \mathrm{mm}^{2}\right)$ \\
\hline & & & 7days & 28days \\
\hline 1 & A1 & 6 & 59.92 & 72.92 \\
\hline 2 & A2 & 6 & 71.55 & 85.34 \\
\hline 3 & A3 & 6 & 81.55 & 84.29 \\
\hline 4 & A4 & 6 & 87.99 & 89.45 \\
\hline 5 & A5 & 6 & 84.88 & 85.26 \\
\hline 6 & MK1 & 6 & 75.37 & 86.41 \\
\hline 7 & MK2 & 6 & 57.99 & 73.36 \\
\hline 8 & MK3 & 6 & 65.13 & 80.83 \\
\hline 9 & MK4 & 6 & 66.67 & 79.89 \\
\hline 10 & MK5 & 6 & 58.25 & 66.00 \\
\hline 11 & G1 & 6 & 68.65 & 73.53 \\
\hline 12 & G2 & 6 & 70.84 & 76.88 \\
\hline 13 & G3 & 6 & 70.85 & 79.88 \\
\hline 14 & G4 & 6 & 85.30 & 89.93 \\
\hline 15 & G5 & 6 & 72.65 & 79.80 \\
\hline 16 & SG1 & 6 & 59.52 & 43.60 \\
\hline 17 & SG2 & 6 & 49.865 & 39.83 \\
\hline 18 & SG3 & 6 & 44.00 & 35.17 \\
\hline 19 & SG4 & 6 & 51.06 & 61.31 \\
\hline 20 & SG5 & 6 & 54.67 & 62.36 \\
\hline 21 & N1 & 6 & 41.20 & 52.17 \\
\hline 22 & N2 & 6 & 38.05 & 46.26 \\
\hline 23 & N3 & 6 & 23.41 & 34.28 \\
\hline 24 & N4 & 6 & 47.59 & 48.13 \\
\hline 25 & N5 & 6 & 52.44 & 58.22 \\
\hline 26 & ST1 & 6 & 65.10 & 65.26 \\
\hline 27 & ST2 & 6 & 60.65 & 53.60 \\
\hline 28 & ST3 & 6 & 58.25 & 56.10 \\
\hline 29 & ST4 & 6 & 42.00 & 45.93 \\
\hline 30 & ST5 & 6 & 48.65 & 70.35 \\
\hline 31 & $\mathrm{C}$ (control mix-only cement) & 6 & 60.69 & 44.18 \\
\hline
\end{tabular}


holding property $\mathrm{b} / \mathrm{w}$ the matrix than Strongcrete is observed. This may be due to the presence of small straight fibers. Flat Crimped steel fiber showed maximum strength of 70.35 $\mathrm{N} / \mathrm{mm}^{2}$. Bonding $\mathrm{b} / \mathrm{w}$ the matrix is more than Strongcrete and Nokrack.

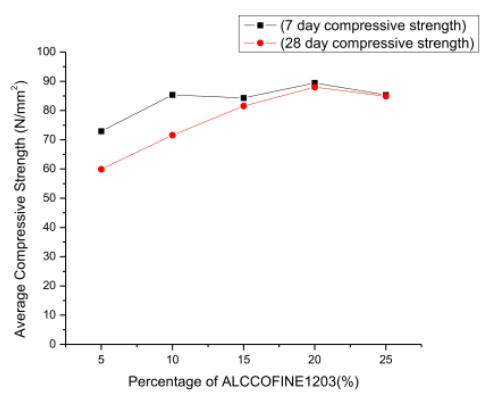

Fig III. Compressive strength Vs Percentage of Alccofine 1203

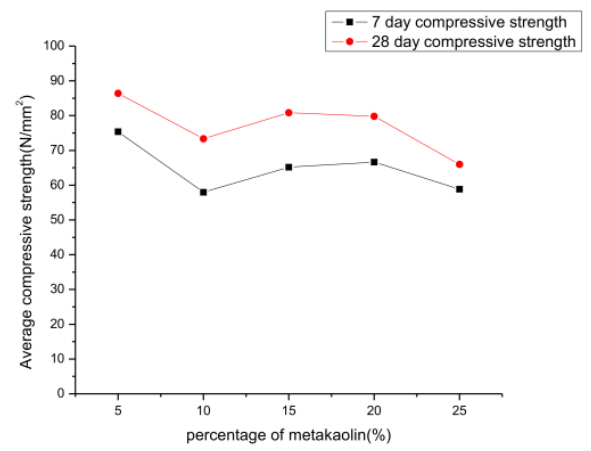

Fig VI. Compressive strength Vs Percentage of Metakaoline

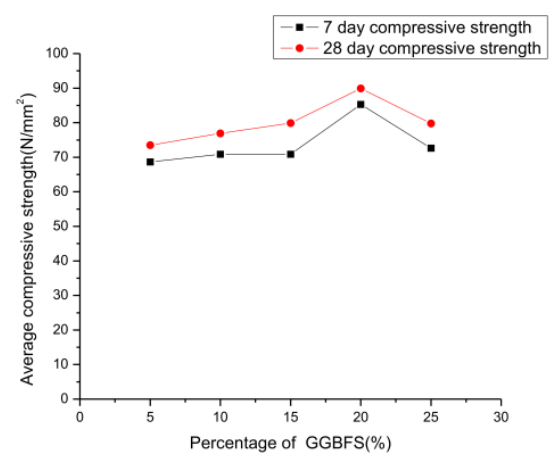

Fig V. Compressive strength Vs Percentage of GGBFS

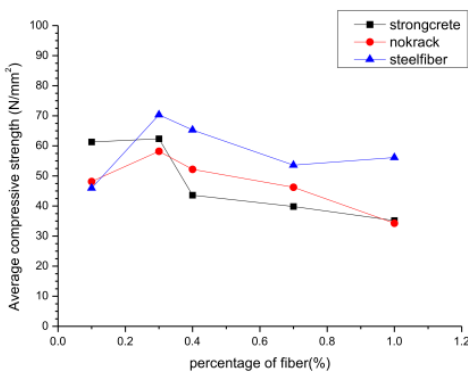

Fig VI. Compressive strength Vs Percentage of Fibers

\section{Conclusions}

On the basis of the results obtained from this research work, the following conclusions have been drawn:

1. With the w/b kept constant at 0.3 , the compressive strength was detrimentally affected by the replacement of cement with Alccofine 1203, metakaolin and GGBS at 7 and 28 days. However, the compressive strength increased at almost all the percentages when compared to control mix. But the target strength of M80 was achieved at $20 \%$ alccofine, $5 \%$ metakaolin and 20\% GGBS replacement levels.

2. The results of the tests carried out for HPC concretes containing Alccofine 1203, metakaolin and GGBS in large volumes clearly illustrated that some mix combinations are superior to others for different properties presented in this paper. Clearly this would mean that HPCs could be designed and produced with a combination of different cementitious materials and the exact choice of these combinations should be based on the physical properties relevant to the performance expected from the HPC.

3. Steel fiber gave better compressive strength than strongcrete and Nokrack fiber. Spalling is less in polymer fiber (Nokrack and Strongcrete).

4. The fibers will tend to transfer the additional stress to the matrix through bond stresses. This process of multiple cracking will continue until either fibers fail or the accumulated local debonding will lead to fiber pull-out.

5. HPC M80 can be made with

- Metakaoline $-5 \%$ replacement of cement

- Alccofine $1203-20 \%$ replacement of cement

- GGBS -20\% replacement of cement.

\section{References}

[1] P.C. Altcin "The durability characteristics of high performance concrete: a review" Cement \& Concrete Composites 25 (2003) 409-420

[2] K.E. Hassan , J.G. Cabrera, R.S. Maliehe "The effect of mineral admixtures on the properties of highperformance concrete" Cement \& Concrete Composites 22 (2000) 267-271

[3] M. I. Khan "Permeation of High Performance Concrete" Journal of materials in civil engineering (C) ASCE January/February 2003.15:84-92.

[4] Drago Saje et al. "Shrinkage of Polypropylene FiberReinforced High-Performance Concrete" Journal of 
materials in civil engineering (C) ASCE / JULY 2011 / 941-952

[5] R. B. Khadiranaikar and Mahesh M. Awati "Concrete Stress Distribution Factors for High-Performance Concrete" Journal of structural engineering (C) ASCE / march 2012.138:402-415.

[6] A Elahi et al. "Mechanical and durability properties of high performance concretes containing supplementary cementitious materials" Construction and Building Materials 24 (2010) 292-299

[7] M.F.M. Zain et al. "Development of high performance concrete using silica fume at relatively high water \pm binder ratios" Cement and Concrete Research 30 (2000) 1501-1505

[8] G. Ghorpade vaishali and h. Sudarsana rao "Strength and permeability characteristics of fiber reinforced high performance concrete with recycled aggregates" Asian journal of civil engineering (building and housing) vol. 13, no. 1 (2012) pages 55-77

[9] Sammy Yin Nin Chan et al." Effect of high temperature and cooling regimes on the compressive strength and pore properties of high performance concrete" Construction and Building Materials 14(2000). 261-266

[10] Hassan et al. "Experimental test methods to determine the uniaxial tensile and compressive behaviour of ultra high performance fibre reinforced concrete (UHPFRC)" Construction and Building Materials 37 (2012) 874-882

[11]Pierre-Claude Aitcin "Developments the application high-performance concretes" Construction and Building Materials, Vol. 9, No. 1, pp. 13-17, 1995

[12]E.H. Kadri , S. Aggoun , G. De Schutter " Interaction between $\mathrm{C} 3 \mathrm{~A}$, silica fume and naphthalene sulphonate superplasticiser in high performance concrete" Construction and Building Materials 23 (2009) 31243128

[13] Peng et al. "Explosive spalling and residual mechanical properties of fiber-toughened high-performance concrete subjected to high temperatures" Cement and Concrete Research 36 (2006) 723-727

[14] Almeida et al. "High-performance concrete with recycled stone slurry" Cement and Concrete Research 37 (2007) $210-220$

[15] Shi Hui-sheng et al. "Influence of mineral admixtures on compressive strength, gas permeability and carbonation of high performance concrete"Construction and Building Materials 23 (2009) 1980-1985

[16] Ping-Kun Chang, Yaw-Nan Peng "Influence of mixing techniques on properties of high performance concrete " Cement and Concrete Research 31 (2001) 87-95

[17] Noumowe et al. "Permeability of high-performance concrete subjected to elevated temperature $\left(600^{\circ} \mathrm{C}\right) "$ Construction and Building Materials 23 (2009). 18551861

[18] Nadeem et al. "Qualitative and quantitative analysis and identification of flaws in the microstructure of fly ash and metakaolin blended high performance concrete after exposure to elevated temperatures" Construction and Building Materials 38 (2013) .731-741
[19] Indrajit Ray et al. "Shrinkage and cracking studies of high performance concrete for bridge decks" Construction and Building Materials 28 (2012) 244-254

[20] Yunsheng Zhang et al. "Study on the hydration heat of binder paste in high-performance concrete" Cement and Concrete Research 32 (2002) 1483-1488

[21] M.F. Mohd Zain, S.S. Radin "Physical properties of high-performance concrete with admixtures exposed to a medium temperature range $20^{\circ} \mathrm{C}$ to $50^{\circ} \mathrm{C}$ " Cement and Concrete Research 30 (2000): 1283-1287

[22] M.F.M. Zain et al. "Development of high performance concrete using silica fume at relatively high water \pm binder ratios" Cement and Concrete Research 30 (2000) 1501-1505

[23] Li Jianyong, Yao Yan "A study on creep and drying shrinkage of high performance concrete" Cement and Concrete Research 31 (2001) 1203-1206

[24]C.S. Poon et al. "Compressive behavior of fiber reinforced high-performance concrete subjected to elevated temperatures" Cement and Concrete Research 34 (2004) 2215-2222

A. Lau, M. Anson "Effect of high temperatures on high performance steel fibre reinforced concrete" Cement and Concrete Research 36 (2006) 1698-1707 